Ann. rheum. Dis. (1963), 22, 11.

\title{
THORAX IN ANKYLOSING SPONDYLITIS
}

\author{
BY \\ F. DUDLEY HART, PETER A. EMERSON, AND IAN GREGG \\ Westminster Hospital, London
}

Rigidity of the thorax in ankylosing spondylitis was first recognized as long ago as 1695 , when Bernard Connor described a skeleton showing the characteristic rigidity of the thoracic cage and lumbar spine and concluded that respiration must have been greatly restricted during the life of the unfortunate sufferer. This astute observation remained the only one of its kind until Hilton Fagge (1877) reported on the ankylosis of the ribs with the vertebrae. However, it is only since 1945 that close attention has been paid to the effect of ankylosing spondylitis on the respiratory system.

Involvement of the thorax is one of the essential features which differentiate ankylosing spondylitis from rheumatoid arthritis. For many years the former condition was considered, largely because of histological similarities, to be a form of rheumatoid arthritis, but there is now wide agreement (13th Rheumatism Review, Smyth and 12 others, 1960) that the two conditions should be clearly distinguished and regarded as separate clinical entities.

The manner in which the thoracic rigidity occurs is well known. Pathological changes occur in any of the articulations of the thorax, progressing to bony ankylosis. The articulations most commonly affected are those between ribs and vertebrae, ankylosis occurring at both the costo-transverse and costo-vertebral joints. In addition to the changes in the spinal column, involvement of the sterno-manubrial and sterno-clavicular joints also contributes to the rigidity of the thorax. In cases where there is severe kyphosis there is gross deformity as well as rigidity of the thorax. As the disease progresses the respiratory movements become more and more restricted until respiration is almost entirely diaphragmatic. Opinion is divided over the position which the ribs take up when ankylosis occurs, some authors finding this to be in inspiration (Travis, Cook, Julian, Crump, Helliesen, Robin, Bayles, and Burwell, 1960; Zorab, 1960), others in expiration (12th Rheumatism Review, 1959; Rogan, Needham, and MacDonald, 1955).

This paper is based on a clinical experience of 360 patients suffering from ankylosing spondylitis who have been referred to Westminster Hospital since 1945. Pulmonary function tests have been performed on 22 patients, none of whom was especially selected on account of thoracic involvement. Clinically these patients showed all degrees of severity of the disease. Studies were also made on normal subjects, in whom thoracic stiffness was simulated by the application of a tight corset.

\section{Clinical Features}

In our experience thoracic rigidity occurs early in ankylosing spondylitis. Objective evidence of thoracic involvement was found in many patients when they first attended the out-patient clinic. The chest expansion was less than 2 in. in 129 ( 70 per cent.) of 184 patients when first seen (Hart and Maclagan, 1955); other workers have also found thoracic rigidity to be an early feature of the disease (Forestier, Jacqueline, and Rotés-Querol, 1956; Romanus and Ydén, 1955).

Symptoms due to thoracic involvement tend to become less obtrusive as the disease progresses and dyspnoea, except in relation to definite exertion, is an uncommon symptom at any stage of the disease. Ordinary respiratory movements are usually painless, but sudden inspiratory movements on coughing, yawning, or sneezing may cause acute discomfort. In a few patients pain is experienced during normal respiration, especially when the sterno-manubrial joint is involved. This joint may be swollen and 
acutely tender and pain may persist for months or years. The ribs, sternum, and costal cartilages may be tender, and this has led to a mistaken diagnosis of Tietze's disease (Tietze, 1921). Ankylosis of the thoracic cage often proceeds insidiously, and we have encountered many patients with greatly reduced chest expansion who have never made a complaint about their chests.

On reviewing the whole series of 360 patients, no undue frequency of lung complications was found. In the first 100 patients who were studied there were three cases of tuberculous pleural effusion, two of active pulmonary tuberculosis, and two of quiescent pulmonary tuberculosis. This early impression led one of us to report an apparent association between ankylosing spondylitis and tuberculosis or other lung infections (Hart, Bogdanovitch, and Nichol, 1950). Many writers believed that in ankylosing spondylitis there was a predisposition to pulmonary tuberculosis (Dunham and Kautz, 1941 ; Lea and Abbatt, 1957). However, no further cases of active pulmonary tuberculosis were encountered in the remainder of our patients, nor have other respiratory infections been prominent. Thus we have been unable to find any evidence that patients with ankylosing spondylitis are especially liable to chest infections or are poor surgical risks because of postoperative chest complications. These findings are in agreement with those of Wilkinson and Bywaters (1958), who found no difference in the incidence of pulmonary complications between 212 patients with ankylosing spondylitis, 253 patients with rheumatoid arthritis, and a random group of controls.

\section{Radiological Features}

In the early stages of ankylosing spondylitis there may be no radiological abnormalities in the thorax. As the condition progresses, blurring of the upper dorsal costo-transverse articulations is usually the first sign to be detected radiologically. Eventually complete bony ankylosis of these ribs to the transverse processes and vertebral bodies is demonstrable, though the progressive obliteration of these joints throughout the length of the dorsal spine may be very difficult to demonstrate even by coned views. In advanced cases the dorsal spine shows splayed triangular shadows where the ribs and vertebrae are fused, each rib appearing to widen as it merges into the dorsal spine.

Involvement of the dorsal spine is first shown by the presence of small stalagmites or stalactites of calcification arising from the edges of the vertebral bodies in the position of the longitudinal ligament. They appear earliest in the lowest two or three dorsal and upper two lumbar vertebrae. Eventually, if the whole vertebral column becomes involved, the typical "bamboo" appearance is seen.

The sterno-manubrial joint is best seen in a lateral projection. Indistinct blurring is the first sign of its involvement; in advanced cases there is complete bony fusion. While bony fusion may be found in the $x$ rays of normal elderly subjects, this is not so in normal younger persons. There is seldom any radiological evidence of sterno-clavicular involvement, even when there are clinical signs of this joint being affected. The bodies of the scapulae often show coarse irregular thickening of their vertebral margins, and the coracoid processes may be similarly affected.

The radiological features of ankylosing spondylitis may be misleading as an index of disability. Patients who show all the radiological changes of an advanced stage of the condition are not necessarily greatly incapacitated. They may be capable of considerable exertion because the diaphragm compensates for the restricted intercostal movements. This can be demonstrated by double exposure radiographs which show wide diaphragmatic excursions, in marked contrast to the restricted intercostal expansion (Hart, Robinson, Allchin, and Maclagan, 1949; Hart and others, 1950).

\section{Pulmonary Function Studies}

Pulmonary function tests were performed in 22 male patients. One patient was excluded from this study because he had a carcinoma of the bronchus; he underwent lobectomy without any pulmonary complications, but died eight months later of generalized metastases. In none of the remaining 21 patients was there clinical evidence of lung disease. Eleven normal male subjects were also studied before and after the application of a tight corset. All the measurements in both patients and normal subjects were made in the sitting position.

The vital capacity and its two sub-divisions, the inspiratory capacity and the expiratory reserve volume, were measured by conventional spirometry. In all but two patients the functional residual capacity was measured, using a closed circuit helium dilution technique (Meneely and Kaltreider, 1941); the residual volume was calculated by subtracting the expiratory reserve volume. All gas volumes were expressed at body temperature and water vapour saturation (B.T.P.S.). The lung compliance was measured in ten patients using the method described by Mead and Whittenberger (1953). 
The results of the investigations in the 21 patients with ankylosing spondylitis and the predicted values for normal subjects of the same age and height are shown in Table I. The predicted vital capacity was derived from the formula of Kory, Callahan, Boren, and Syner (1961) based on height and age, and the predicted lung compliances were derived from the formula of Frank, Mead, Siebens, and Storey (1956) based on height. As a result of kyphosis, flexion of the neck, or ankylosis of the hips, the height of several patients was considerably less than it had been before the onset of their disease. Therefore, whenever patients were able to recall accurately their original height, this was used for the purpose of prediction. The predicted total lung capacity was found from the predicted vital capacity by applying the formula of Baldwin, Cournand, and Richards (1948).

TABLE I

RESULTS IN 21 PATIENTS WITH ANKYLOSING SPONDYLITIS AND PREDICTED VALUES

\begin{tabular}{|c|c|c|c|c|c|c|c|c|c|c|c|c|c|c|}
\hline \multirow{2}{*}{$\begin{array}{l}\text { Case } \\
\text { No. }\end{array}$} & \multirow{2}{*}{$\begin{array}{c}\text { Age } \\
\text { (yrs) }\end{array}$} & \multirow{2}{*}{$\begin{array}{l}\text { Height } \\
\text { (in.) }\end{array}$} & \multicolumn{2}{|c|}{$\begin{array}{l}\text { Vital } \\
\text { Canacity } \\
\text { (litres) }\end{array}$} & \multicolumn{2}{|c|}{$\begin{array}{c}\text { Inspiratory } \\
\text { Caoacity } \\
\text { (litres) }\end{array}$} & \multicolumn{2}{|c|}{$\begin{array}{c}\text { Expiration Resi- } \\
\text { dual Volume } \\
\text { (litres) }\end{array}$} & \multicolumn{2}{|c|}{$\begin{array}{l}\text { Residual } \\
\text { Volume } \\
\text { (litres) }\end{array}$} & \multicolumn{2}{|c|}{$\begin{array}{c}\text { Functional Resi- } \\
\text { dual Capacity } \\
\text { (litres) }\end{array}$} & \multicolumn{2}{|c|}{$\begin{array}{c}\text { Total } \\
\text { Lung } \\
\text { Capacity }\end{array}$} \\
\hline & & & $\begin{array}{c}\text { Ob- } \\
\text { served }\end{array}$ & $\begin{array}{c}\text { Pre- } \\
\text { dicted }\end{array}$ & $\begin{array}{c}\text { Ob- } \\
\text { served }\end{array}$ & $\begin{array}{l}\text { Pre- } \\
\text { dicted }\end{array}$ & $\begin{array}{c}\text { Ob- } \\
\text { served }\end{array}$ & $\begin{array}{l}\text { Pre- } \\
\text { dicted }\end{array}$ & $\begin{array}{c}\text { Ob- } \\
\text { served }\end{array}$ & $\begin{array}{c}\text { Pre- } \\
\text { dicted }\end{array}$ & $\begin{array}{c}\text { Ob- } \\
\text { served }\end{array}$ & $\begin{array}{l}\text { Pre- } \\
\text { dicted }\end{array}$ & $\begin{array}{c}\text { Ob- } \\
\text { served }\end{array}$ & $\begin{array}{l}\text { Pre- } \\
\text { dicted }\end{array}$ \\
\hline 1 & 48 & 68 & $3 \cdot 24$ & $4 \cdot 38$ & $1 \cdot 83$ & $3 \cdot 28$ & $1 \cdot 41$ & $1 \cdot 10$ & $1 \cdot 63$ & $1 \cdot 35$ & $3 \cdot 04$ & $2 \cdot 45$ & $4 \cdot 87$ & $5 \cdot 73$ \\
\hline 2 & 23 & $68 \cdot 5$ & $4 \cdot 24$ & $5 \cdot 02$ & $2 \cdot 15$ & $3 \cdot 76$ & $2 \cdot 09$ & $1 \cdot 26$ & $1 \cdot 10$ & $1 \cdot 25$ & $3 \cdot 19$ & $2 \cdot 51$ & $5 \cdot 34$ & $6 \cdot 27$ \\
\hline 3 & 36 & $66 \cdot 5^{*}$ & $3 \cdot 74$ & $4 \cdot 45$ & $2 \cdot 22$ & $3 \cdot 34$ & $1 \cdot 52$ & $1 \cdot 11$ & - & - & - & - & - & - \\
\hline 4 & 45 & $72 *$ & $3 \cdot 29$ & $4 \cdot 98$ & $1 \cdot 84$ & $3 \cdot 74$ & $1 \cdot 45$ & $1 \cdot 24$ & $2 \cdot 14$ & $1 \cdot 52$ & $3 \cdot 59$ & $2 \cdot 76$ & $5 \cdot 43$ & $6 \cdot 50$ \\
\hline 5 & 37 & 70 & $3 \cdot 49$ & $4 \cdot 90$ & $1 \cdot 88$ & $3 \cdot 68$ & $1 \cdot 61$ & $1 \cdot 22$ & - & - & - & - & - & - \\
\hline 6 & 52 & $69 *$ & $2 \cdot 16$ & $4 \cdot 43$ & $1 \cdot 42$ & $3 \cdot 33$ & 0.74 & $1 \cdot 10$ & 3.09 & $1 \cdot 98$ & $3 \cdot 83$ & $3 \cdot 08$ & $5 \cdot 25$ & $6 \cdot 41$ \\
\hline 7 & 58 & $64^{*}$ & $1 \cdot 86$ & $3 \cdot 60$ & $1 \cdot 36$ & $2 \cdot 80$ & 0.50 & 0.80 & $2 \cdot 80$ & $1 \cdot 61$ & $3 \cdot 30$ & $2 \cdot 41$ & $4 \cdot 66$ & $5 \cdot 21$ \\
\hline 8 & 25 & 66 & $3 \cdot 43$ & $4 \cdot 64$ & $2 \cdot 21$ & $3 \cdot 48$ & $1 \cdot 22$ & $1 \cdot 16$ & $1 \cdot 46$ & $1 \cdot 16$ & $2 \cdot 68$ & $2 \cdot 32$ & $4 \cdot 89$ & $5 \cdot 80$ \\
\hline 9 & 52 & $71^{*}$ & $2 \cdot 47$ & $4 \cdot 70$ & $1 \cdot 35$ & $3 \cdot 53$ & $1 \cdot 12$ & $1 \cdot 17$ & $2 \cdot 84$ & $2 \cdot 11$ & $3 \cdot 96$ & $3 \cdot 28$ & $5 \cdot 31$ & $6 \cdot 81$ \\
\hline 10 & 55 & 72 & $4 \cdot 55$ & $4 \cdot 78$ & $2 \cdot 37$ & $3 \cdot 59$ & $2 \cdot 18$ & $1 \cdot 19$ & $3 \cdot 11$ & $2 \cdot 14$ & $5 \cdot 29$ & $3 \cdot 33$ & $7 \cdot 66$ & $6 \cdot 92$ \\
\hline 11 & 32 & 66 & $3 \cdot 56$ & $4 \cdot 48$ & $1 \cdot 96$ & $3 \cdot 36$ & $1 \cdot 60$ & $1 \cdot 12$ & $1 \cdot 90$ & $1 \cdot 12$ & $3 \cdot 50$ & $3 \cdot 24$ & $5 \cdot 46$ & $5 \cdot 60$ \\
\hline 12 & 37 & $72 *$ & $2 \cdot 47$ & $5 \cdot 18$ & $1 \cdot 55$ & $3 \cdot 89$ & 0.92 & $1 \cdot 29$ & $1 \cdot 60$ & $1 \cdot 58$ & $2 \cdot 52$ & $2 \cdot 87$ & $4 \cdot 07$ & $6 \cdot 76$ \\
\hline 13 & 36 & 71 & $3 \cdot 50$ & $5 \cdot 07$ & $2 \cdot 51$ & $3 \cdot 81$ & 0.99 & $1 \cdot 26$ & $1 \cdot 31$ & $1 \cdot 55$ & $2 \cdot 30$ & $2 \cdot 81$ & $4 \cdot 81$ & $6 \cdot 62$ \\
\hline 14 & 54 & $68 \cdot 5$ & $3 \cdot 46$ & $4 \cdot 32$ & $2 \cdot 18$ & $3 \cdot 24$ & $1 \cdot 28$ & $1 \cdot 08$ & $2 \cdot 14$ & 1.93 & $3 \cdot 42$ & 3.01 & $5 \cdot 60$ & $6 \cdot 25$ \\
\hline 15 & 25 & 67 & $3 \cdot 37$ & $4 \cdot 78$ & $2 \cdot 28$ & $3 \cdot 59$ & $1 \cdot 09$ & $1 \cdot 19$ & $2 \cdot 13$ & $1 \cdot 20$ & $3 \cdot 22$ & $2 \cdot 39$ & $5 \cdot 50$ & $5 \cdot 98$ \\
\hline 16 & 57 & 68 & 3.05 & $4 \cdot 20$ & 1.96 & $3 \cdot 15$ & 1.09 & $1 \cdot 05$ & $2 \cdot 88$ & $1 \cdot 88$ & $3 \cdot 97$ & $2 \cdot 93$ & $5 \cdot 93$ & 6.08 \\
\hline 17 & 29 & 72 & $4 \cdot 20$ & $5 \cdot 37$ & $2 \cdot 50$ & $4 \cdot 03$ & $1 \cdot 70$ & $1 \cdot 34$ & $1 \cdot 34$ & $1 \cdot 34$ & $3 \cdot 04$ & $2 \cdot 68$ & $5 \cdot 54$ & $6 \cdot 71$ \\
\hline 18 & 25 & $71^{*}$ & $2 \cdot 44$ & $5 \cdot 32$ & $1 \cdot 43$ & 3.99 & $1 \cdot 01$ & $1 \cdot 33$ & $1 \cdot 93$ & $1 \cdot 33$ & $2 \cdot 94$ & $2 \cdot 66$ & $4 \cdot 37$ & $6 \cdot 65$ \\
\hline 19 & 28 & $73 *$ & $3 \cdot 94$ & $5 \cdot 52$ & $2 \cdot 50$ & $4 \cdot 14$ & $1 \cdot 44$ & $1 \cdot 38$ & $2 \cdot 11$ & $1 \cdot 38$ & $3 \cdot 55$ & $2 \cdot 76$ & $6 \cdot 05$ & $6 \cdot 90$ \\
\hline 20 & 49 & $68^{*}$ & $2 \cdot 35$ & $4 \cdot 36$ & $1 \cdot 16$ & $3 \cdot 27$ & $1 \cdot 19$ & $1 \cdot 09$ & $1 \cdot 13$ & $1 \cdot 33$ & $2 \cdot 32$ & $2 \cdot 42$ & $3 \cdot 48$ & $5 \cdot 69$ \\
\hline 21 & 33 & 67 & $1 \cdot 89$ & $4 \cdot 60$ & $1 \cdot 32$ & $3 \cdot 45$ & 0.57 & $1 \cdot 15$ & 3.05 & $1 \cdot 15$ & $3 \cdot 62$ & $2 \cdot 30$ & $4 \cdot 94$ & $5 \cdot 75$ \\
\hline MEANS & $\ldots$ & $\cdots$ & $3 \cdot 17$ & $4 \cdot 72$ & $1 \cdot 90$ & $3 \cdot 54$ & $1 \cdot 27$ & $1 \cdot 18$ & $2 \cdot 09$ & $1 \cdot 52$ & $3 \cdot 33$ & $2 \cdot 69$ & $5 \cdot 22$ & $6 \cdot 24$ \\
\hline \multicolumn{3}{|c|}{ Standard Deviation } & $0 \cdot 761$ & 0.443 & 0.429 & $0 \cdot 103$ & 0.424 & $0 \cdot 122$ & 0.674 & 0.325 & 0.675 & $0 \cdot 320$ & 0.839 & 0.496 \\
\hline \multicolumn{3}{|c|}{$\begin{array}{c}\text { Standard Error of } \\
\text { Difference }\end{array}$} & \multicolumn{2}{|c|}{$0 \cdot 192$} & \multicolumn{2}{|c|}{0.096} & \multicolumn{2}{|c|}{0.096} & \multicolumn{2}{|c|}{$0 \cdot 172$} & \multicolumn{2}{|c|}{$0 \cdot 164$} & \multicolumn{2}{|c|}{$0 \cdot 224$} \\
\hline
\end{tabular}

* Original heights before the onset of ankylosing spondylitis. 
Airway resistance was assessed in all 21 patients by measuring the peak expiratory flow rate with a Wright peak expiratory flow meter (Wright and McKerrow, 1959) and by measuring the percentage of the forced expiratory volume expired in the first second. These results are shown in Table II. Total thoracic compliance was measured in fifteen patients, using a method which will be described elsewhere. Its principle is to measure the volume change in the resting expiratory level produced by measured increase in the pressure of the air breathed at the mouth. The results, expressed in litres of volume change per $\mathrm{cm}$. water pressure change, are shown in Table II.

The lung volumes and the total thoracic compliance were also estimated in seven normal subjects before and after the application of a corset: these results are shown in Table III (opposite).

\section{Discussion}

There was a consistent and significant reduction in the vital capacity of the patients with ankylosing spondylitis. The mean value was $3 \cdot 17$ litres (S.D. $=0 \cdot 761), 67$ per cent. of the mean predicted value of 4.72 litres (S.D. $=0.443$; standard error of difference of the means $=0 \cdot 192$ ). Even in two patients (Cases 2 and 17) in whom the disease had begun within the previous 3 years and who were unaware of any chest restriction, the vital capacity was significantly reduced. Since the report by one of us (Hart and others, 1950) of the reduction in vital capacity in ankylosing spondylitis, many other workers have confirmed this finding. Our present study shows that the reduction of vital capacity is due to limitation of inspiratory excursion, whereas expiration is nearly always unimpaired. Thus the

TABLE II

RESULTS OF TESTS OF AIRWAY RESISTANCE IN 21 PATIENTS WITH ANKYLOSING SPONDYLITIS

\begin{tabular}{|c|c|c|c|c|c|c|c|}
\hline \multirow{2}{*}{$\begin{array}{l}\text { Case } \\
\text { No. }\end{array}$} & \multirow{2}{*}{$\begin{array}{l}\text { Age } \\
(\mathrm{yrs})\end{array}$} & \multirow{2}{*}{$\begin{array}{l}\text { Height } \\
\text { (in.) }\end{array}$} & \multirow{2}{*}{$\begin{array}{l}\text { Forced Expiratory } \\
\text { Volume } 1 \text { sec. } \\
\text { (per cent.) }\end{array}$} & \multirow{2}{*}{$\begin{array}{l}\text { Peak Expiratory } \\
\text { Flow Rate } \\
\text { (litres/min.) }\end{array}$} & \multirow{2}{*}{$\begin{array}{l}\text { Total Thoracic } \\
\text { Compliance } \\
\text { (litres } / \mathrm{cm} . \mathrm{H}_{2} \mathrm{O} \text { ) }\end{array}$} & \multicolumn{2}{|c|}{$\begin{array}{l}\text { Lung Compliance } \\
\text { (litres } / \mathrm{cm} . \mathrm{H}_{2} \mathrm{O} \text { ) }\end{array}$} \\
\hline & & & & & & Observed & $\begin{array}{c}\text { Predicted from } \\
\text { Height }\end{array}$ \\
\hline 1 & 48 & 68 & 84 & 500 & 0.078 & - & - \\
\hline 2 & 23 & $68 \cdot 5$ & 84 & 440 & 0.060 & - & - \\
\hline 3 & 36 & $66 \cdot 5^{*}$ & 93 & 580 & - & $0 \cdot 128$ & $0 \cdot 154$ \\
\hline 4 & 45 & 72 & 70 & 480 & - & 0.113 & $0 \cdot 202$ \\
\hline 5 & 37 & 70 & 100 & 460 & - & 0.145 & $0 \cdot 185$ \\
\hline 6 & 52 & $69^{*}$ & 68 & 315 & - & $0 \cdot 160$ & $0 \cdot 184$ \\
\hline 7 & 58 & $64^{*}$ & 77 & 390 & - & $0 \cdot 145$ & $0 \cdot 132$ \\
\hline 8 & 25 & 66 & 95 & 470 & 0.048 & - & - \\
\hline 9 & 52 & $71^{*}$ & 82 & 350 & 0.038 & - & - \\
\hline 10 & 55 & 72 & 96 & 450 & 0.065 & - & - \\
\hline 11 & 32 & 66 & 90 & 420 & 0.043 & - & - \\
\hline 12 & 37 & $72^{*}$ & 88 & 480 & 0.066 & - & - \\
\hline 13 & 36 & 71 & 87 & 610 & 0.070 & $0 \cdot 195$ & $0 \cdot 194$ \\
\hline 14 & 54 & $68 \cdot 5$ & 79 & 450 & 0.048 & $0 \cdot 171$ & $0 \cdot 172$ \\
\hline 15 & 25 & 67 & 88 & 440 & 0.045 & $0 \cdot 147$ & $0 \cdot 158$ \\
\hline 16 & 57 & 68 & 97 & 380 & 0.075 & - & - \\
\hline 17 & 29 & 72 & 89 & 580 & 0.65 & - & - \\
\hline 18 & 25 & $71^{*}$ & 100 & 480 & 0.043 & - & - \\
\hline 19 & 28 & $73^{*}$ & 92 & 600 & 0.060 & $0 \cdot 163$ & 0.211 \\
\hline 20 & 49 & $68^{*}$ & 97 & 450 & 0.031 & - & - \\
\hline 21 & 33 & 67 & 100 & 480 & - & $0 \cdot 150$ & $0 \cdot 158$ \\
\hline
\end{tabular}

* Original heights before the onset of ankylosing spondylitis. 
TABLE III

EFFECTS OF CORSETING IN SEVEN NORMAL SUBJECTS

\begin{tabular}{|c|c|c|c|c|c|c|c|c|c|c|c|c|c|c|c|c|}
\hline \multirow[t]{2}{*}{$\begin{array}{l}\text { Case } \\
\text { No. }\end{array}$} & \multirow[t]{2}{*}{$\begin{array}{l}\text { Age } \\
\text { (yrs) }\end{array}$} & \multirow[t]{2}{*}{$\begin{array}{l}\text { Height } \\
\text { (in.) }\end{array}$} & \multicolumn{2}{|c|}{$\begin{array}{c}\text { Vital } \\
\text { Capacity } \\
\text { (litres) }\end{array}$} & \multicolumn{2}{|c|}{$\begin{array}{l}\text { Inspiratory } \\
\text { Capacity } \\
\text { (litres) }\end{array}$} & \multicolumn{2}{|c|}{$\begin{array}{l}\text { Expiratory } \\
\text { Residual } \\
\text { Volume } \\
\text { (litres) }\end{array}$} & \multicolumn{2}{|c|}{$\begin{array}{c}\text { Functional } \\
\text { Residual } \\
\text { Capacity } \\
\text { (litres) }\end{array}$} & \multicolumn{2}{|c|}{$\begin{array}{l}\text { Residual } \\
\text { Volume } \\
\text { (litres) }\end{array}$} & \multicolumn{2}{|c|}{$\begin{array}{c}\text { Total Lung } \\
\text { Capacity } \\
\text { (litres) }\end{array}$} & \multicolumn{2}{|c|}{$\begin{array}{c}\text { Total Thoracic } \\
\text { Compliance } \\
\text { (litres } / \mathrm{cm} . \mathrm{H}_{2} \mathrm{O} \text { ) }\end{array}$} \\
\hline & & & $\begin{array}{c}\text { Nor- } \\
\text { mal }\end{array}$ & $\begin{array}{l}\text { Cor- } \\
\text { seted }\end{array}$ & $\begin{array}{c}\text { Nor- } \\
\text { nal }\end{array}$ & $\begin{array}{l}\text { Cor- } \\
\text { seted }\end{array}$ & $\begin{array}{l}\text { Nor- } \\
\text { mal }\end{array}$ & $\begin{array}{l}\text { Cor- } \\
\text { seled }\end{array}$ & $\begin{array}{c}\text { Nor- } \\
\text { mal }\end{array}$ & $\begin{array}{l}\text { Cor- } \\
\text { seted }\end{array}$ & $\begin{array}{l}\text { Nor- } \\
\text { mal }\end{array}$ & $\begin{array}{l}\text { Cor- } \\
\text { seted }\end{array}$ & $\begin{array}{l}\text { Nor- } \\
\text { nual }\end{array}$ & $\begin{array}{l}\text { Cor- } \\
\text { seted }\end{array}$ & $\begin{array}{c}\text { Nor- } \\
\text { mal }\end{array}$ & $\begin{array}{l}\text { Cor- } \\
\text { seted }\end{array}$ \\
\hline 1 & 35 & 69 & $4 \cdot 63$ & $2 \cdot 33$ & $3 \cdot 13$ & $1 \cdot 28$ & $1 \cdot 50$ & $1 \cdot 05$ & $3 \cdot 42$ & $2 \cdot 95$ & $1 \cdot 92$ & $1 \cdot 90$ & $6 \cdot 55$ & $4 \cdot 23$ & $0 \cdot 100$ & $0 \cdot 044$ \\
\hline 2 & 36 & 65 & $4 \cdot 65$ & $2 \cdot 21$ & 3.05 & $1 \cdot 44$ & $1 \cdot 60$ & 0.77 & $2 \cdot 91$ & $2 \cdot 11$ & $1 \cdot 31$ &.$\cdot 34$ & $5 \cdot 96$ & $3 \cdot 55$ & 0.076 & 0.038 \\
\hline 3 & 39 & 64 & $3 \cdot 21$ & $2 \cdot 34$ & $2 \cdot 67$ & $1 \cdot 77$ & 0.54 & 0.57 & $1 \cdot 91$ & $1 \cdot 97$ & $1 \cdot 47$ & $1 \cdot 40$ & $4 \cdot 58$ & $3 \cdot 74$ & 0.047 & 0.041 \\
\hline 4 & 22 & 70 & $5 \cdot 67$ & $4 \cdot 11$ & $3 \cdot 42$ & $2 \cdot 27$ & $2 \cdot 25$ & $1 \cdot 84$ & $3 \cdot 42$ & $3 \cdot 07$ & $1 \cdot 17$ & $1 \cdot 23$ & $6 \cdot 84$ & $5 \cdot 34$ & $0 \cdot 132$ & 0.066 \\
\hline 5 & 22 & 72 & $5 \cdot 40$ & $4 \cdot 71$ & $3 \cdot 27$ & $2 \cdot 94$ & $2 \cdot 13$ & $1 \cdot 77$ & $3 \cdot 93$ & $2 \cdot 52$ & $1 \cdot 80$ & $1 \cdot 75$ & $7 \cdot 20$ & $5 \cdot 46$ & $0 \cdot 130$ & 0.081 \\
\hline 6 & 23 & 75 & $4 \cdot 62$ & $2 \cdot 49$ & $2 \cdot 82$ & $1 \cdot 44$ & $1 \cdot 80$ & $1 \cdot 05$ & $4 \cdot 55$ & $3 \cdot 89$ & $2 \cdot 75$ & $2 \cdot 84$ & $7 \cdot 37$ & $5 \cdot 33$ & 0.085 & $0 \cdot 048$ \\
\hline 7 & 38 & 67 & $4 \cdot 89$ & $3 \cdot 12$ & $3 \cdot 54$ & $2 \cdot 04$ & $1 \cdot 35$ & $1 \cdot 08$ & $3 \cdot 12$ & $3 \cdot 00$ & $1 \cdot 77$ & $1 \cdot 92$ & $6 \cdot 66$ & $5 \cdot 04$ & $0 \cdot 105$ & $0 \cdot 042$ \\
\hline
\end{tabular}

mean value for the inspiratory capacity was 1.90 litres (S.D. $=0.429$ ), 54 per cent. of the mean predicted value of 3.54 litres (S.D. $=0.103$; standard error of difference of the means $=0.096$ ), whereas the mean value for the expiratory reserve volume was 1.27 litres, 108 per cent. of the mean predicted value of $1 \cdot 18$ litres. The residual volumes and functional residual capacities showed considerable variations above and below the predicted values, but the mean value for the residual volume was 2.09 litres (S.D. $=0.674$ ), 137 per cent. of the mean predicted value of 1.52 litres (S.D. $=0.325$; standard error of difference of the means $=0 \cdot 172$ ).
This difference is therefore significant.

Fig. 1 shows diagrammatically the proportional changes in the mean lung volumes in the present series of patients with ankylosing spondylitis, compared to the mean predicted values.

In our patients there was no evidence of emphysema or other obstructive airway disease to account for the increase in the residual volume. The peak expiratory flow rates and the percentages of forced expiratory volume expired in one second were all within normal limits. Other workers have similarly found that the airway resistance in ankylosing spondylitis was normal (Louyot, Girard, Sadoul, and
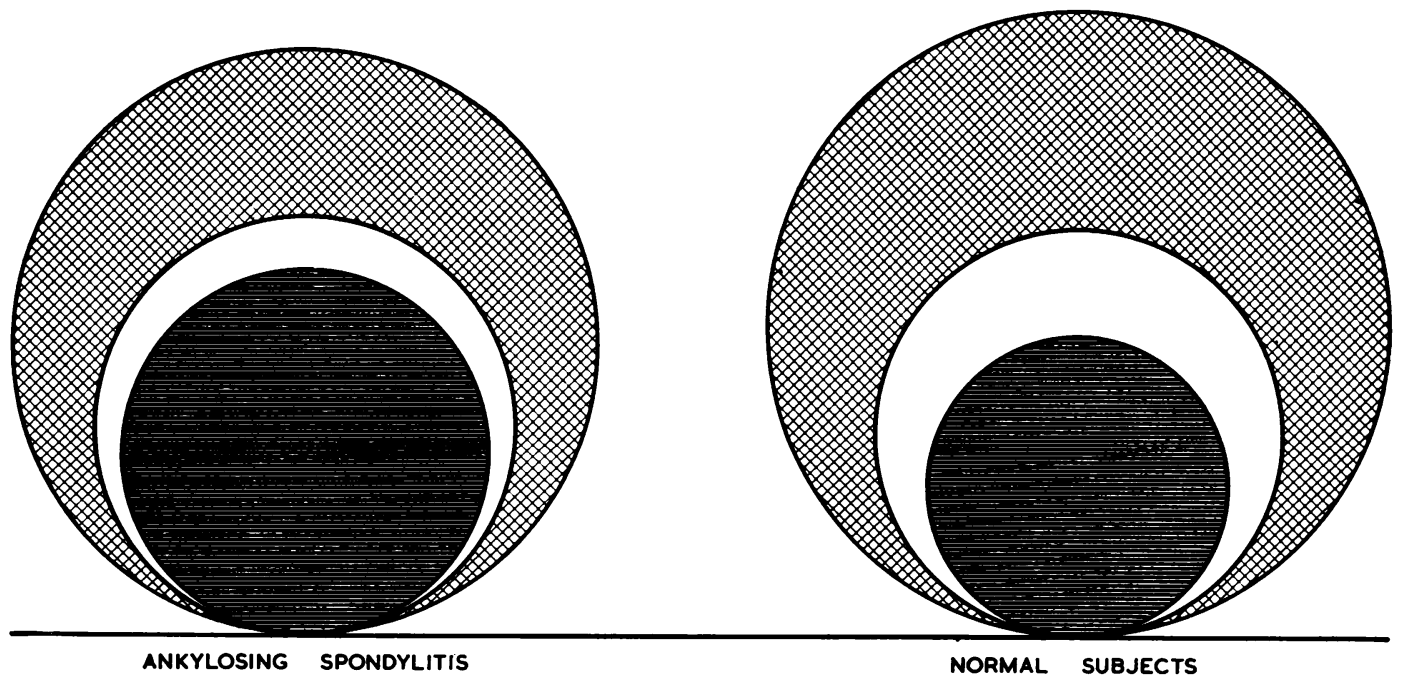

Fig. 1.-Diagrammatic comparison of the mean lung volumes of patients with ankylosing spondylitis with the mean predicted values. 
Grilliat, 1951; D'Silva, Freeland, and Kazantzis, 1953). Intra-pulmonary mixing has been measured and found to be normal (Rogan and others, 1955; Renzetti, Nicholas, Dutton, and Jivoff, 1960; Travis and others, 1960).

Not all workers have found an increase in the residual volume in ankylosing spondylitis. Rogan and others (1955) found normal residual volumes in 35 patients, while Renzetti and others (1960) found only a small increase. On the other hand, Travis and others (1960) found that the mean residual volume in eleven patients was double the mean predicted value, while Zorab (1962), in a study of 35 patients, found the mean residual volume to be 125 per cent. of the mean predicted value.

The size of the residual volume is important in understanding the disorder of the mechanics of respiration in ankylosing spondylitis. Our findings and those of Travis and others (1960) and Zorab (1962) indicate that ankylosis of the thoracic cage occurs with the ribs in a position of partial inspiration, the increase in residual vclume and functional residual capacity being a consequence of a rise in the resting expiratory level. This conclusion and the findings on which it is based is therefore in direct disagreement with those of Smyth and others, the editors of the 12th Rheumatism Review (1959), who stated that "the units become fixed in the position of expiration", and "the residual volume remained about normal in mean value".

In our patients the total lung capacity was found to be significantly reduced. The mean value was $5 \cdot 22$ litres (S.D. $=0.839$ ), 84 per cent. of the mean predicted value of 6.24 litres (standard error of difference of the means $=0 \cdot 224$ ). This reduction in total lung capacity indicates that ankylosing spondylitis is truly a restrictive disorder. Similar findings were reported by Rogan and others (1955) and Renzetti and others (1960), but Travis and others (1960) and Zorab (1962) found that the total lung capacity was normal or slightly increased. A possible explanation for these contradictory findings may be found in a difference of method in obtaining the predicted values. Travis and others (1960) and Zorab (1962) obtained their predicted values from the present heights of their patients, whereas we felt that the original heights, if known accurately, were a more accurate guide to what the lung volumes should have bzen if the patients had not developed ankylosing spondylitis.

The pattern of the lung volumes in patients with ankylosing spondylitis stands in sharp contrast to that which was found when normal subjects were tightly corseted. Table III shows that corseting caused a reduction in vital capacity, inspiratory capacity, and total lung capacity, as was expected. In addition, the expiratory reserve volume was reduced by corseting, whereas in the ankylosing spondylitic patients it was normal. No change in the residual volume occurred. These experiments confirm our belief that in ankylosing spondylitis the thorax does not become fixed in a position of expiration, but in a position of partial inflation which cannot be simulated by corseting.

The results for the total thoracic compliances of ankylosing spondylitic patients are shown in Table II. In Fig. 2 the results of total chest compliance are plotted against the same subject's functional residual capacity. The regression line for the normal male chest wall compliance $(y)$ on function residual capacity in litres $(x)$ is $y=0 \cdot 018 x+0 \cdot 030$. This regression line for normal males is drawn on the graph, together with shading representing the 95 per cent. limits for the line. The patients with ankylosing spondylitis are represented by the solid circles, nearly all of which fall below the 95 per cent. limit, indicating a significant increase in the stiffness of the total chest in patients with ankylosing spondylitis.

There was close agreement between the observed and predicted values for lung compliance in all but three of the ankylosing spondylitic patients.

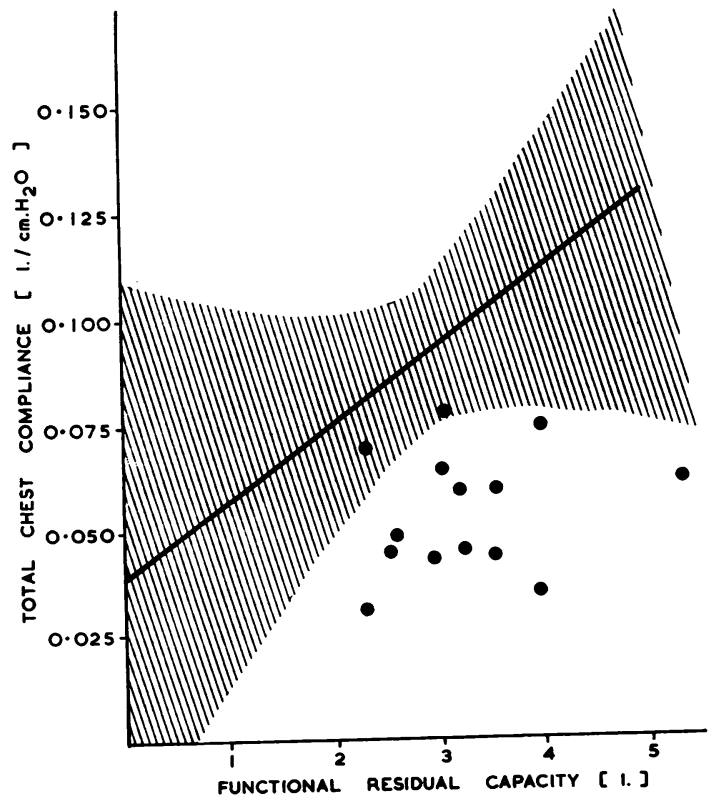

Fig. 2.-Relationship between functional residual capacity and total chest compliance. The regression line for the normal male chest is shown, the shaded area representing the 95 per cent. limits for the line. The dots represent the results obtained for the patients with ankylosing spondylitis. 
Some workers have reported a reduction in lung compliance in ankylosing spondylitis. Travis and others (1960) found a significant reduction in all but two of nine patients who had no complicating pulmonary disease, but were unable to tell if the reduction in compliance was caused by intrinsic changes in the lungs themselves or was merely a mechanical result of the restricted thoracic cage. Zorab (1962) also found that lung compliance was reduced, particularly in those patients with the most severe restriction. However, he could find no evidence of any pulmonary fibrosis or other significant lung pathology on autopsy examination of eight patients.

In our patients not only were the lung compliance values within normal limits, but also there was neither radiological nor clinical evidence of any abnormality in the lungs themselves. It seems likely therefore that the increased stiffness of the total chest in these patients with ankylosing spondylitis was entirely due to the abnormal stiffness of the chest wall itself.

\section{Summary}

In 360 patients with ankylosing spondylitis, thoracic involvement was a common and relatively early occurrence. The symptoms, clinical signs, and radiological appearances of such involvement are described. There was no evidence that patients with ankylosing spondylitis showed any predisposition to pulmonary tuberculosis or other respiratory infections.

The chest expansion was usually diminished, being less than 2 in. in 129 (70 per cent.) of 184 patients at their initial attendance. In 21 male patients in whom pulmonary function was assessed, the mean vital capacity (3.17 litres) was 67 per cent. of the mean predicted value (4.72 litres). The reduction occurred at the expense of the inspiratory capacity (mean value 1.93 litres compared with mean predicted value of 3.48 litres). The mean value of the expiratory reserve volume was not significantly different from the mean predicted value. The residual volume showed considerable variation, but the mean value (2.09 litres) was increased to 135 per cent. of the mean predicted value ( $1 \cdot 25$ litres). There was no evidence of emphysema or other obstructive airway disease and it was concluded that, in ankylosing spondylitis, the chest wall is not only restricted in its excursion, but is also held in a position of partial inspiration. These changes were in contrast to those found in seven normal subjects when tightly corseted. These normal subjects showed a decrease in both the inspiratory capacity and the expiratory reserve volume and no significant change in the residual volume.

Measurement of the total chest compliance confirmed the presence of increased stiffness of the chest wall in the patients with ankylosing spondylitis. There was no evidence that the lungs were abnormally stiff in ankylosing spondylitis and it was concluded that the reduction in the total compliance was due to rigidity of the thoracic cage.

It is a pleasure to acknowledge the help that we have had from Dr. P. Cliffe, Mr. D. Strickland, and Dr. R. G. W. Manley of the Department of Clinical Measurement, Westminster Hospital.

\section{REFERENCES}

Baldwin, E. de, Cournand, A., and Richards, D. W. (1948). Medicine, 27, 243.

Connor, B. (1695). Philos. Trans., 19, 21. (Quoted by Blumberg, B. S. (1958). Arthr. and Rheum., 1, 553.)

D'Silva, J. L., Freeland, D. E., and Kazantzis, G. (1953). Thorax, 8, 303.

Dunham, C. L., and Kautz, F. G. (1941). Amer. J. med. Sci., 201, 232.

Fagge, C. Hilton (1877). Trans. path. Soc. Lond., 28, 201.

Forestier, J., Jacqueline, F., and Rotés-Querol, J. (1956). “Ankylosing Spondylitis", p. 120. Thomas, Springfield, Ill.

Frank, N. R., Mead, J., Siebens, A. A., and Storey, C. F. (1956). J. appl. Physiol., 9, 38.

Hart, F. Dudley, Bogdanovitch, A., and Nichol, W. D. (1950). Ann. rheum. Dis., 9, 116. and Maclagan, N. F. (1955). Ibid., 14, 77.

-, Robinson, K. C., Allchin, F. M., and Maclagan, N. F. (1949). Quart. J. Med., 18, 217.

Kory, R. C., Callahan, R., Boren, H. G., and Syner, J. C. (1961). Amer. J. Med., 30, 243.

Lea, A. J., and Abbatt, J. D. (1957). Lancet, $2,917$.

Louyot, P., Girard, J., Sadoul, P., and Grilliat, J. P. (1951). Rev. Rhum., 18, 679.

Mead, J., and Whittenberger, J. L. (1953). J. appl. Physiol., 5, 779.

Meneely, G. R., and Kaltreider, N. L. (1941). Proc. Soc. exp. Biol. (N.Y.), 46, 91 .

Renzetti, A. D., Nicholas, W., Dutton, R. E., and Jivoff, L. (1960). New Engl. J. Med., 262, 215.

Rogan, M. C., Needham, C. D., and McDonald, I. (1955). Clin. Sci., 14, 91 .

Romanus, R., and Ydén, S. (1955). "Pelvo-spondylitis ossificans", p. 59. Munksgaard, Copenhagen.

Smyth, C. J., and 12 others (1959). 12th Rheumatism Review, Ann. intern. Med., 50, 434.

- (1960). 13th Rheumatism Review, Ibid., 53, No. 7.

Tietze, A. (1921). Berl. klin. Wschr., 58, 829. 
Travis, D. M., Cook, C. D., Julian, D. G., Crump, C. H., Helliesen, P., Robin, E. D., Bayles, T. B., and Burwell, C. S. (1960). Amer. J. Med., 29, 623.

Wilkinson, M., and Bywaters, E. G. L. (1958). Ann. rheum. Dis., 17, 209.

Wright, B. M., and McKerrow, C. B. (1959). Brit. med. J., 2, 1041.

Zorab, P. A. (1962). Quart. J. Med., 31, 267.

\section{Le thorax dans la spondylarthrite ankylosante}

\section{RÉSUMÉ}

Chez 360 malades atteints de spondylarthrite ankylosante, l'implication thoracique était commune et relativement précoce. On décrit ici les symptômes, signes cliniques et l'apparence radiologique de cette implication. On ne trouva pas de preuves indiquant une prédisposition des malades atteints de spondylarthrite ankylosante à la tuberculose pulmonaire ou à une autre infection respiratoire.

L'ampliation thoracique était généralement diminuée, moins de $5 \mathrm{~cm}$. chez $129(70 \%)$ sur 184 malades à leur examen initial. Chez 21 hommes dont la fonction pulmonaire avait été déterminée, la capacité vitale moyenne (3,17 litres) était $67 \%$ de la valeur moyenne prévue (4,72 litres). Cette réduction s'est produite aux dépens de la capacité inspiratoire (valeur moyenne de 1,93 litre comparée à la valeur moyenne prévue de 3,48 litres). La valeur moyenne du volume de la reserve expiratoire n'était pas appréciablement différente de la valeur moyenne prévue. Le volume résiduel accusait des variations considérables, mais la valeur moyenne $(2,09$ litres) était élévée à $135 \%$ de la valeur moyenne prévue (1,25 litres). On n'a pas trouvé de signes d'emphysème ou d'autre maladie capable de produire l'occlusion des voies respiratoires et on a conclu que, dans la spondylarthrite ankylosante, la paroi thoracique n'est pas seulement restreinte en son ampliation, mais aussi tenue en position d'inspiration partielle. Ces altérations faisaient contraste avec celles trouvées chez sept sujets normaux mis dans un corset serré. Ces sujets accusaient une diminution de la capacité inspiratoire et du volume de la reserve expiratoire, sans altération appréciable du volume résiduel.

La mesure du pliage thoracique total a confirmé la présence d'une rigidité augmentée de la paroi thoracique chez des malades atteints de spondylarthrite ankylosante. On n'a pas trouvé de signes de rigidité anormale des poumons dans la spondylarthrite ankylosante et on a conclu que la réduction du pliage total était due à la rigidité de la cage thoracique.

\section{El torax en la espondilartritis anquilosante}

\section{SUMARIO}

En 360 enfermos con espondilartritis anquilosante la implicación torácica fué común y relativamente precoz. Se describen aquí los síntomas, signos clínicos y el cuadro radiológico de esta implicación. No se encontraron datos indicando que los enfermos con espondilartritis anquilosante fuesen predispuestos a la tuberculosis pulmonar o a otras infecciones respiratorias.

La expansión torácica fué generalmente disminuida, siendo debajo de $5 \mathrm{~cm}$. en $129(70 \%)$ sobre 184 enfermos examinados por la primera vez. En 21 enfermos masculinos cuya función pulmonar había sido determinada, la capacidad vital media $(3,17$ litros) dué un $67 \%$ del valor medio anticipado (4,72 litros). Esta reducción se produjo a costa de la capacidad inspiratoria (valor medio de 1,93 litros ccmparado con el valor medio anticipado de 3,48 litros). El valor medio del volumen de la reserva expiratoria no fué apreciablemente diferente del valor medio anticipado. El volumen residual acusó variaciones considerables, pero el valor medio $(2,09$ litros) subió a un $135 \%$ del valor medio anticipado $(1,25$ litros). No se encontró evidencia de enfisema o de otra enfermedad capaz de causar oclusión de vías respiratorias y se concluyó que en la espondilartritis anquilosante la pared torácica se ve no sólo restringida en su expansión, sino también mantenida en posición deç inspiración parcial. Estas alteraciones contrastan con las observadas en siete sujetos normales estrechamente encorsetados. Estos acusaron una disminución de la capacidad inspiratoria y del volumen de la reserva expiratoria, sin alteración apreciable del volumen residual.

La medida de la función mecánica total del tórax confirmó el aumento de la rigidez de la pared torácica en enfermos con espondilartritis anquilosante. No se vieron signos de rigidez anormal de los pulmones en la espondilartritis anquilosante y se concluyó que la reducción de la función mecánica total del tórax fué debida a la rigidez de la pared torácica. 